\title{
ALTERAÇÃO SUPERGÊNICA DO DEPÓSITO DE COBRE-OURO DO SALOBO, SERRA DOS CARAJÁS-PA - ÊNFASE NO COMPORTAMENTO DO COBRE
}

\section{EVALDO RAIMUNDO PINTO DA SILVA ${ }^{1}$ \& BASILE KOTSCHOUBEY ${ }^{2}$}

\begin{abstract}
SUPERGENE ALTERATION OF THE COPPER-GOLD DEPOSIT OF SALOBO, CARAJÁS REGIOIN, PARÁ: ENPHASIS ON THE BEHAVIOR OF COPPER The weathering mantle of the Salobo deposit was developed upon metagraywackes with interbedded lens of iron formations. The profile is of the truncated type and constituted, from the base to the top, of a transition horizon, a saprolitic horizon and colluvial deposits. The two former horizons show lateral, textural and mineralogical variations which reflect the heterogeneous nature of the parent rock. Thus, alteration of the barren graywackes resulted essentially in the formation of a saprolite rich in clay minerals (hydrobiotite, smectite, kaolinite). On the other hand, weathering of the iron formations, host-rocks of copper sulfides (bornite, calcocite, chalcopyrite), originated a gossan type profile composed from the base to the top of a supergene sulfide zone, an oxidized minerals zone and a ferruginous saprolite. The supergene sulfides are digenite, covellite and bornite (?) while cuprite, malachite, azurite and native copper constitute the oxidized copper assemblage. Within the saprolite, smectite and goethite are the main copper enriched minerals.

The evolution of such supergene setting involved oxidization and dissolution of primary sulfides with mobilization of $\mathrm{Cu}$ and Fe as soluble sulfatos. The downward and lateral transfer of these metals caused the formation of new mineral associations according to the $\mathrm{Cu} / \mathrm{S}$ ratio in the solutions and the ambient $\mathrm{pH}$ and Eh conditions. In the reducing zone the ionic exchange between copper sulfate and primary sulfides yielded mainly digenite and covellite, while in the water-table fluctuation zone and immediately above, in more oxidizing conditions, copper precipitated as cuprite and native metal. Besides, reaction of copper sulfate with calcite from veins that cuts iron formations resulted in the fixation of $\mathrm{Cu}$ as malachite and azurite in neutral to alkaline conditions.

In the Carajás region, the lateritic mantle was formed during the Lower Tertiary, but; during the Upper Tertiary and Quaternary, underwent dissection due to regional uplift. Thus, in the Salobo area, the duricrust and the upper saprolite were removed. Each phase of lowering of the hydrostatic level resulted in the deepenning of the weathering profile and alteration, in oxidizing conditions, of previously formed supergene oxides and sulfides. One parte of the released copper then underwent downward leaching and reprecipitation in deeper reconstituted cementation and oxidation zones, while another part was fixed by neoformed goethite and clay-minerals.
\end{abstract}

Keywords: supergene alteration, gossan, secundary sulfides, weathering profile.

RESUMO O manto de intemperismo no depósito do Salobo desenvolveu-se sobre metagrauvacas com intercalações de lentes de formação ferrífera. O perfil é do tipo truncado e constituído, da base para o topo, por um horizonte de transição, um horizonte saprolítico e um nível coluvial. Os dois primeiros horizontes exibem variações laterais, texturais e mineralógicas, que refletem a natureza heterogênea da rocha matriz. Assim, o intemperismo das metagrauvacas estéreis resultou em formação de um saprólito rico em argilominerais (hidrobiotita, esmectita e caolinita). Por sua vez, a alteração das formações ferríferas hospedeiras dos sulfetos de cobre (bornita, calcocita, calcopirita) originou um perfil do tipo "gossan" composto da base para o topo por uma zona de sulfetos supergênicos, uma zona de minerais oxidados e um saprólito ferruginoso. Os sulfetos supergênicos são essencialmente digenita, covelita e bornita (?), enquanto que os minerais oxidados são cuprita, malaquita e azurita. Cobre nativo ocorre na porção inferior da zona oxidada. No saprólito, as principais fases portadoras de cobre são esmectita e goethita.

A evolução deste quadro supergênico envolveu a dissolução dos sulfetos primários na zona de oxidação e a mobilização do Cu e do Fe sob a forma de sulfatos. A migração das soluç̃̃es em direção ao lençol freático resultou em formação de novas associações minerais em equíbrio com a razão $\mathrm{Cu} / \mathrm{S}$ nas soluções $\mathrm{e}$ as condições de $\mathrm{Eh} \mathrm{e} \mathrm{pH}$ do meio. Na zona redutora do perfil de alteração a troca iônica entre o sulfato de cobre e os sulfetos primários deu orígem a digenita e a covelita, enquanto que na zona de flutuação do lençol freático e logo acima, em condições mais oxidantes, o cobre precipitou na forma de cuprita e de metal nativo. Por outro lado, a reação do sulfato com a calcita dos veios que cortam as formações ferríferas permitiu a fixação de $\mathrm{Cu}$ na forma de malaquita e de azurita em condições de $\mathrm{pH}$ neutro a alcalino.

Na região de Carajás, o manto Iaterítico formou-se durante o Terciário Inferior, porém, no Terciário Superior e no Quaternário, sofreu forte dissecação devida a um lento soerguimento tectônico regional. Assim, na área Salobo, a couraça e o saprólito superior foram intensamente removidos. Concomitantemente, durante o rebaixamento do nível hidrostático e consequiente aprofundamento do perfil, houve a desestabilização dos minerais secundários previamente gerados (óxidos e sulfetos), sendo parte do cobre lixiviada per descensum e reprecipitada nas zonas de cimentação e oxidação reconstituídas a maior profundidade, enquanto que outra parte foi fixada in situ por goethita e argilominerais neoformados.

Palavras-Chaves: alteração supergênica, gossan, sulfetos secundários, perfil de intemperismo.

INTRODUÇÃo O depósito de $\mathrm{Cu}(\mathrm{Au}, \mathrm{Ag}, \mathrm{Mo})$ do Salobo, localizado na Província Mineral dos Carajás, no Sudeste do Estado do Pará (Fig. 1), comporta uma espessa cobertura de alteração, na qual ocorrem, localmente, significativas concentrações de Cu e Au.

De início os estudos enfocaram essencialmente o minério secundário de cobre, com o objetivo de definir o modo de ocorrência deste elemento no perfil de alteração e as transformações sofridas pelos minerais primários no ambiente supergênico (Veiga 1983, Toledo-Groke $e t$ al. 1985, Toledo-Groke 1986, Ildefonse et al. 1986, Toledo-Groke et al. 1987, Santos 1989, Flores 1989). De forma geral, estes trabalhos concluiram que o cobre não constitui mineral próprio no minério alterado. No entanto, este elemento, embora ausente nos silicatos primários, encontra-se em teores significativos nos seus produtos de alteração. Segundo Toledo-Groke et al. (1987) as principais fases fixadoras do cobre no minério secundário do Salobo são: vermiculita, esmectita e interestratificados do tipo biotita-vermiculita resultantes da transformação da biotita; goethita derivada da transformação pseudomórfica da granada e do anfibólio e criptomelana e goethita, alojadas nos sistemas fissurais.

No final da década de 80, a Companhia Docegeo, procurando avaliar o potencial da cobertura residual do Salobo em termos de

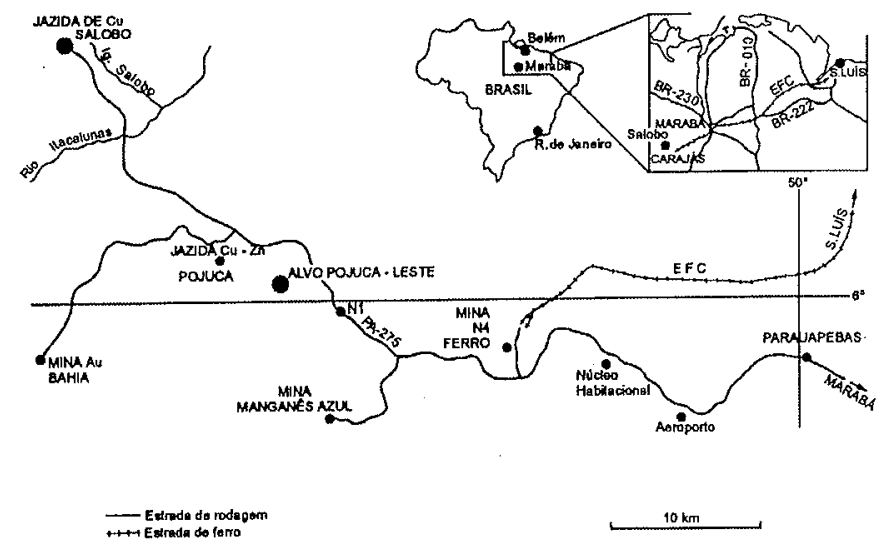

Figura 1-Mapa de localização do depósito de cobre do Salobo.

1 Centro de Geociências, Departamento de Geologia, Universidade Federal do Pará - Caixa Postal 1611, Fax(091) 211-1609, Belém-Pará-Brasil, CEP- 66017970, e-mail: keyte@amazon.com.br

2 Centro de Geociências, Departamento de Geoquímica e Petrologia, Universidade Federal do Pará - Caixa Postal 1611, Fax (091) 211-1478, Belém-ParáBrasil, CEP-66017-970, e-mail: cpgg@ufpa.br 
mineralização aurífera, executou inúmeros furos de sondagem e poços de pesquisa na área do depósito. Essas investigações permitiram um melhor entendimento da estruturação do perfil de alteração e dos fenômenos que afetaram o minério primário e a sua rocha hospedeira. Mais recentemente, o primeiro autor deste trabalho desenvolveu uma tese de doutorado na referida área, visando esclarecer a natureza e a orígem da mineralização aurífera supergênica (Pinto da Silva 1996). Constatouse que a presença de sulfetos na rocha matriz teve forte influência sobre a evolução do manto intempérico, que adquiriu acentuadas características gossânicas. Deste modo, o processo de alteração resultou no enriquecimento em cobre e em ouro em vários níveis do perfil.

O presente artigo é baseado na referida tese de doutorado e tem como objetivo principal enfocar a evolução da cobertura de alteração do depósito do Salobo, enfatizando as transformações sofridas pelos sulfetos de cobre e pelas suas rochas hospedeiras. A caracterização da mineralização aurífera supergênica e a discussão refente à sua orígem serão temas de outra publicação.

MÉTODOS Nesta pesquisa foram utilizadas informações de 10 furos de sondagem executados pela Companhia DOCEGEO em uma seção transversal ao depósito do Salobo (Fig. 3). Para estudos de detalhe foram selecionadas 40 amostras representativas do perfil de alteração nos furos F/73, F/79 e F/81 da referida seção. Estudos petrográficos e minerográficos foram efetuados nas amostras de rocha fresca e de rocha pouco alterada. Por sua vez, a composição mineralógica do material alterado foi determinada por difração de raios $\mathrm{x}$, com auxílio eventual da espectroscopia no infravermelho. Com base na comparação entre os picos encontrados na difração de raios $\mathrm{x}$ e os padrões apresentados na literatura (Carrol 1974, Van Olphen \& Fripiart 1979) foi feita uma avaliação qualitativa da cristalinidade dos minerais secundários. A composição química dos oxi-hidróxidos de ferro foi determinada por microssonda eletrônica e a substituição isomórfica do $\mathrm{FeOOH}$ pelo $\mathrm{AlOOH}$ na goethita foi avaliada com base na metodologia proposta por Solymar (1969).

QUADRO GEOLÓGICO DA JAZIDA - CORPO C O depósito do Salobo situa-se na aba norte da Serra dos Carajás e inclui-se num conjunto de serras orientadas na direção WNW/ESE de extensão total de mais de 10 quilômetros. Trata-se de um relevo de feições assimétricas cujas cotas mais elevadas - 450 metros - apresentam um desnível da ordem de 250 metros em relação ao topo dos platôs residuais da região de Carajás.

O contexto geológico do depósito consiste em gnáisses do Complexo Xingu, rochas metassedimentares da Sequência Salobo, pequenas intrusões de rochas granitóides e diques de diabásio (Vieira et al. 1988 , Lindenmayer 1990).

$\mathrm{Na}$ área do depósito propriamente dito, ocorrem essencialmente rochas da Sequência Salobo (Lindenmayer 1990), particularmente bem representadas no denominado corpo $\mathrm{C}$, localizado na porção mediana da zona mineralizada (Fig. 2). Neste setor a Sequência Salobo possui uma espessura da ordem de 300 a 600 metros e é composta por formacões ferríferas, metagrauvacas, quartzitos arcosianos e anfibolitos subordinados.

As formações ferríferas ocupam a porção intermediária do corpo $\mathrm{C}$ sendo balizadas a norte e a sul pelas metagrauvacas, com as quais apresentam contatos gradativos. Elas ocorrem sob a forma de lentes de espessura centimétrica a métrica, posicionadas subverticalmente e orientadas na direção $\mathrm{N} 70^{\circ} \mathrm{W}$. Com base em critérios químicos e mineralógicos essas rochas foram classificadas em dois tipos principais (Lindenmayer 1990, Réquia 1995): Formações ferríferas de Tipo I, de textura maciça a levemente foliada, compostas de magnetita (50-90\%)fayalita-grunerita com quantidades subordinadas de biotita, hastingsita, almandina e greenalita e Formações ferríferas de Tipo II, de textura foliada e constituídas por magnetita (15-50\%)-biotita-gruneritaalmandina e por quantidades subordinadas de quartzo, clorita e turmalina.

As metagrauvacas são as rochas mais comuns na jazida do Salobo. Elas exibem contatos por zonas de cisalhamento, a norte com os quartzitos e, a sul, com os gnaisses do embasamento. São rochas normalmente foliadas, compostas principalmente de biotita, almandina $\mathrm{e}$ quartzo, bem como de muscovita, plagioclásio, turmalina e magnetita em quantidades subordinadas. $O$ conteúdo de magnetita varia de 0 a $15 \%$, sendo mais elevado nas zonas de contato com as formações ferríferas, na porção central da jazida..
Os quartzitos ocupam toda a borda meridional da jazida e sustentam o relevo local. São constituídos por quartzo (75-90\%) e por quantidades variáveis de muscovita, K-feldspato, clorita, sillimanita, biotita, granada e magnetita.

Os anfibolitos ocorrem em corpos isolados, de espessura métrica, intercalados no pacote de metagrauvacas. São compostos de anfíbólio (cummingtonita-hornblenda), plagioclásio (oligoclásio-andesina) e de biotita e quartzo em quantidades menores.

Veios e vênulas de espessura milimétrica a centimétrica ocorrem comumente alojados nas rochas da Sequência Salobo. São compostos essencialmente de quartzo-turmalina, fluorita-greenalita, quartzocalcita-clorita-bornita, calcita-fluorita, stilpnomelana-clorita, quartzoalbita e molibdenita.

MINÉRIO PRIMÁRIO O minério do depósito sulfetado do Salobo é composto por bornita, calcocita e quantidades menores de calcopirita. Estão igualmente presentes molibdenita, cobaltita, saflorita e ouro nativo. Esses minerais ocorrem disseminados nas formações ferríferas, havendo uma correlação positiva entre a sua abundância e o conteúdo de magnetita. Da mesma forma, observa-se uma relação entre a natureza dos sulfetos de cobre e a composição da rocha hospedeira. Assim, a calcopirita ocorre preferencialmente associada às formações ferríferas de Tipo I, especialmente àquelas ricas em fayalita, enquanto que a bornita e a calcocita são mais abundantes nas formações ferríferas de Tipo II, particularmente naquelas compostas de magnetita, grunerita, biotita e clorita. Em termos texturais, a calcopirita ocorre em cristais anédricos a subédricos, ocupando os espaços entre os cristais de fayalita e de grunerita, formando filmes em torno da granada, da fayalita e da hastingsita, ou na forma de lamelas inseridas nos planos de clivagem da grunerita. Localmente a calcopirita aparece na forma de finas lamelas de exsolução orientadas segundo os planos de clivagem da bornita (Fig. 7A). Esta última encontra-se em grãos anédricos a subédricos apresentando contatos retos com a magnetita, ou na forma de lamelas inseridas nos planos de clivagem da grunerita e da biotita e nas fraturas da granada. Seus contatos com a calcopirita são as vezes irregulares, destacando-se golfos de bornita na calcopirita, sugerindo a substituição deste último mineral. A calcocita apresenta-se em cristais anédricos, na forma de inclusões ou de intercrescimentos mirmequíticos em cristais de bornita que sugerem exsolução a baixa temperatura (Craig \& Vaughan 1981) (Fig. 7C). Localmente, a

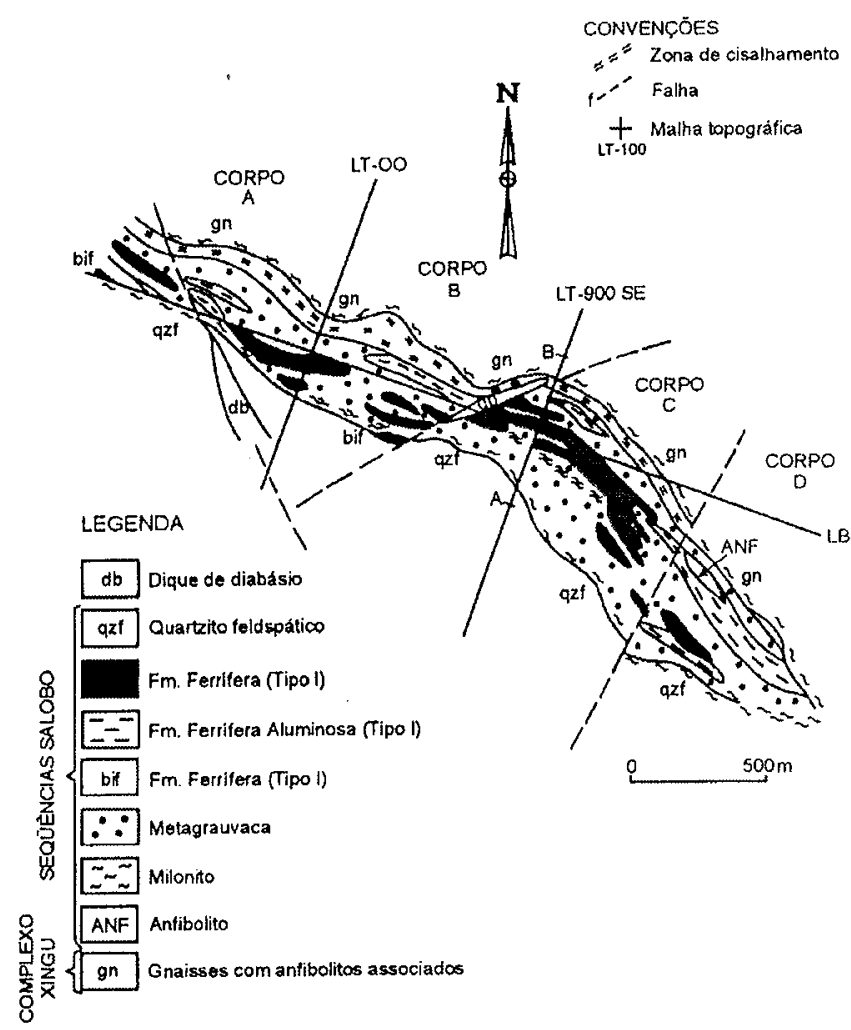

Figura 2 - Mapa geológico do depósito do Salobo (nivel topográfico 250) 
calcocita forma auréolas em torno de cristais de bornita e invade a parte interna destes últimos, denotando substituição. A calcocita aparece ainda na forma de lamelas inseridas em planos de clivagem da biotita e em fraturas da granada. Por fim, a bornita e a calcocita preenchem fraturas ou constituem vênulas que cortam ocasionalmente as formações ferríferas do Tipo II. Os cristais são anédricos e exibem contatos irregulares que sugerem a substituição da bornita pela calcocita.

No minério de cobre do Salobo, o ouro ocorre em partículas visíveis em veios de quartzo + carbonato que cortam as formações ferríferas do Tipo $\mathrm{II}$, bem como na forma de inclusões microscópicas e submicroscópicas nos minerais de minério das formações ferríferas, incluindo sulfoarsenietos (cobaltita), diarsenietos (saflorita), calcopirita e magnetita (Lindenmayer 1990, Pinto da Silva et al. 1991, Figueiredo et al. 1993, Réquia et al. 1994, Pinto da Silva 1996). Em termos de importância econômica o segundo tipo é de longe o mais relevante, tendo em vista a pouca abundância dos veios nas formações ferrifferas.

\section{COBERTURA DE ALTERAÇÃo As sequências vulcano-} sedimentares da região de Carajás são capeadas por uma espessa cobertura laterítica, formada provavelmente no Terciário Inferior. Durante o Terciário Superior e o Quaternário, um lento soerguimento tectônico regional levou a dissecação do manto laterítico pretérito e a individualização dos vastos platôs atualmente observados na região (Kotschoubey et al. 1989, Souza \& Kotschoubey 1991, Maurity \& Kotschoubey 1995). No caso do depósito do Salobo, o manto laterítico lá presente é de tipo truncado. Sua espessura varia de 50 metros, no domínio das formações ferríferas, até 80 metros, no domínio das metagrauvacas (Fig. 3). Em termos gerais o perfil ć composto, da base para o topo, por um horizonte de rocha semi-alterada (horizonte de transição), um horizonte saprolítico e um nível coluvial. Nos dois primeiros horizontes observam-se variações laterais em termos de textura e de composição mineralógica, que refletem a composição heterogênea do substrato e a posição subvertical das rochas que o constituem.

Perfil de alteração sobre as metagrauvacas Sobre as grauvacas formaram-se produtos de alteração essencialmente argilosos devidos à abundância dos silicatos (biotita, almandina, grunerita, principalmente) e ao baixo conteúdo de magnetita $(<15 \%)$ nas rochas matrizes. Da base para o topo, o perfil divide-se em zona de transição, saprólito e cobertura coluvial.

ZONADE TRANSIÇÃO Este horizonte marca a passagem gradativa da rocha fresca para o saprólito. Sua espessura é de até 25 metros nas

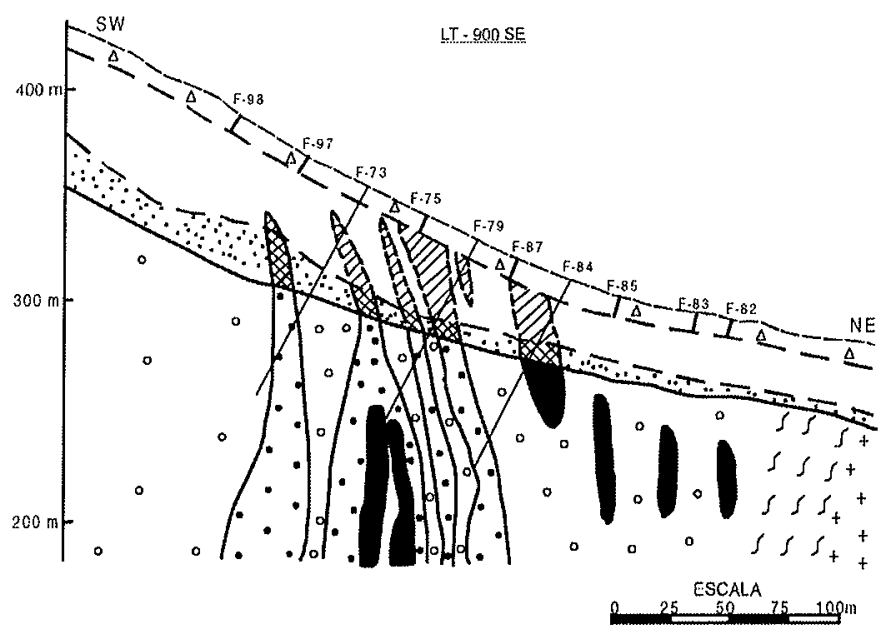

LEGENDA

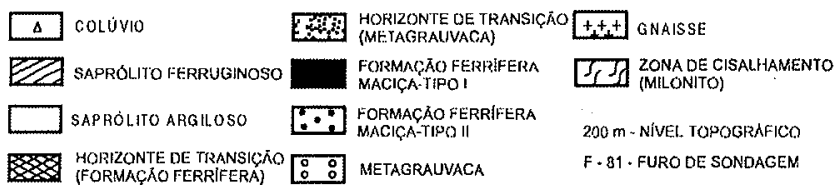

Figura 3- Estrutura da cobertura de alteração da jazida do Salobo (seção transversal 900SE). partes mais elevadas da serra, porém diminui em direção ao sopé (Fig. 3). A rocha apresenta-se fortemente fraturada e a sua coloração varia de cinza-esverdeada na base do horizonte a amarelada no seu topo. Localmente, na sua parte inferior, ainda ocorrem fragmentos da rocha matriz parcialmente preservados. $O$ processo de alteração inicia-se com o desenvolvimento de um sistema fissural, no qual aparecem concentrações de goethita e eventualmente de esmectita. A textura original da rocha é ainda bem preservada, embora os minerais apresentem. transformações bastante acentuadas.

A cor da biotita varia de esverdeada, na rocha sã, a amarelada na porção superior do horizonte, percebendo-se um enfraquecimento progressivo do pleocroísmo. Os espaços interlamelares são alargados e ocupados por um plasma argilo-ferruginoso de coloração cinzaesverdeada a amarelada. Em direção ao topo do horizonte, esse plasma é progressivamente invadido por pontuações avermelhadas que evoluem para minúsculas concreções de oxi-hidróxido de ferro. Segundo Toledo-Groke (1986) essas transformações resultam na formação de um mineral interestratificado do tipo biotita-vermiculita, o qual, no presente trabalho, não pode ser individualizado, sendo denominado genericamente de hidrobiotita (Wilson 1970, Brindley et al. 1983). Este mineral, por sua vez, evolui para esmectita e goethita em direção ao topo do horizonte. O anfibólio e a granada, mais suscetíveis à alteração que a biotita, são rapidamente desestabilizados na zona de transição. A alteração desses minerais inicía-se ao longo dos planos de clivagem do anfibólio e nas fraturas da granada. Nessas descontinuidades, desenvolve-se inicialmente um plasma de coloração cinza-esverdeada a amarelada, a qual, em direção ao topo do horizonte, muda para tonalidades avermelhadas com a intensificação da oxidação. O plasma invade progressivamente os minerais até a formação, no final, de pseudomorfos de oxi-hidróxido de ferro. Conforme observado por Toledo-Groke et al. (1987), o anfibólio altera-se inicialmente para um filossilicato do tipo vermiculita ou esmectita, passando gradativamente, com o aumento da lixiviação, para produtos ferruginosos contendo até $4 \%$ de $\mathrm{CuO}$. Por sua vêz, a granada sofre diretamente uma alteração pseudomórfica para oxi-hidróxido de ferro com até $5 \%$ de $\mathrm{CuO}$, formando estruturas em "box work" mais densas do que no caso dos anfibólios.

Minerais secundários de cobre são relativamente raros no horizonte de transição sobre as metagrauvacas. Trata-se essencialmente de malaquita depositada em fraturas, na base do horizonte.

HORIZONTE SAPROLITICO Este horizonte é constituído por um material argiloso, que ainda exibe, de modo mais ou menos marcante, uma textura reliquiar. Localmente, na base do horizonte, ainda estão presentes fragmentos da rocha matriz com núcleos parcialmente preservados. Em amostras de testemunhos de sondagem (F/73) observase que a coloração do saprólito varia da base para o topo do horizonte de cinza-esverdeada a amarela-avermelhada. A composição mineralógica e a textura sofrem igualmente modificações. $\mathrm{Da}$ base do horizonte - a cerca de 28 metros de profundidade - até $18 \mathrm{~m}$ da superfície, a xistosidade da rocha ainda é bem perceptível. O saprólito compõe-se de fragmentos líticos pouco coesos, imersos em matriz argilosa, constituída por hidrobiotita, esmectita, goethita e hematita. Esmectita verde (nontronita) e goethita preenchem o sistema fissural. A partir de 18 metros de profundidade até o topo do horizonte, o material torna-se friável e fracamente estruturado. Os minerais predominantes são caolinita, goethita e hematita. Conforme demonstrado pelo padrão dos picos nos difratogramas de raios $\mathrm{x}$, a caolinita exibe baixo grau de cristalinidade e aparece no perfil concomitantemente com o desaparecimento da esmectita. As fraturas são comumente preenchidas por goethita e criptomelana. Os minerais residuais mais frequentes são quartzo, turmalina e granadas ferruginizadas. A distribuição irregular desses minerais no saprólito reflete as variações na composição da rocha matriz.

COLÚVIO Este material recobre toda a encosta norte da Serra do Salobo e possui uma espessura máxima de 5 metros no sopé da serra. Ao longo da encosta, no entanto, sua espessura varia bastante devido a recentes movimentos do solo provocados pela atividade antropogênica na área (desmatamento para abertura de estradas, galerias e praças de sondagem). Trata-se de um material mal selecionado, composto de fragmentos milimétricos a centimétricos de rocha alterada (metagrauvaca e formação ferrífera) e de veios de quartzo, imersos em matriz argilosa de coloração avermelhada, constituída essencialmente 
de goethita, caolinita e quartzo. Na parte superior do colúvio desenvolve-se um horizonte orgânico de cerca de 0,3 metros de espessura.

Perfil de alteração sobre as formações ferríferas $O$ perfil intempérico desenvolvido sobre as formações ferríferas comporta os mesmos horizontes que o perfil sobre as metagrauvacas. Neste caso, no entanto, a composição heterogênea da rocha matriz refletiuse na formação de produtos de alteração algo variados em termos texturais e mineralógicos, o que torna o perfil mais complexo. Além disso, a oxidação dos sulfetos causou a geração de minerais secundários, os quais coexistem com os produtos da lateritização. Este quadro supergênico híbrido está bem representado nos perfís de sondagem $\mathrm{F} /$ 79 e F/81 (Figs. 4 e 5).

ZONA DE TRANSIÇĀO Esta zona possui espessura entre 15 e 18 metros e exibe natureza heterogênea. Tal fato é ilustrado no perfil $F / 81$ (Fig. 5) no qual o contato é gradativo entre formações ferríferas do Tipo II e formações ferríferas do Tipo I, na passagem da rocha sã para a rocha semi-alterada. Por outro lado, no perfil F/79, ocorrem apenas formações ferríferas do Tipo II (Fig. 4).

Em ambos os perfís, os primeiros sinais de alteração supergênica consistem em modificações na coloração das rochas e no aparecimento de oxi-hidróxido de ferro e de esmectita no sistema fissural. A coloração preta-esverdeada das formações ferríferas do Tipo I muda para marrom-avermelhada no topo do horizonte. Por sua vez, as tonalidades cinza-esverdeadas das formações ferríferas do Tipo II passam para tonalidades amarelas-avermelhadas na parte superior dessa zona. Essas últimas rochas, mostram-se menos coesas que as anteriores e exibem um aspecto lustroso, ressaltado pelas palhetas de hidrobiotita.

Sob o microscópio, os minerais das formações ferríferas revelam acentuadas modificações. A coloração da biotita muda de esverdeada na rocha sã para amarela-pálida na rocha semi-alterada. No estágio incipiente de alteração, este mineral comporta filmes de oxi-hidróxido de ferro nos espaços interlamelares e nas bordas dos cristais. À medida que a alteração progride, a biotita perde o seu pleocroísmo e mostra um crescente alargamento dos espaços interlamelares, os quais são ocupados por um plasma argilo-ferruginoso de coloração amarelada a avermelhada. Este plasma contém diminutas zonas avermelhadas de segregação de oxi-hidróxido de ferro num fundo matricial de coloração amarelada. A alteração da biotita resulta na formação de hidrobiotita e esmectita, as quais persistem até o topo do horizonte. Grunerita e granada sofrem transformação pseudomórfica, sendo substituídas progressivamente por oxi-hidróxido de ferro a partir dos planos de clivagem e de fraturas, respectivamente. No estágio inicial da alteração, estes espaços são ocupados por um plasma de coloração amarelada, no qual ocorrem diminutas zonas de concentração de oxihidróxido de ferro de coloração avermelhada. Graciativamente, os produtos ferruginosos invadem os minerais primários a medida que estes vão se degradando. Ao contrário do que acontece com a biotita, esta transformação completa-se logo na porção inferior do horizonte. A magnetita, por sua vez, transforma-se em hematita pelo processo de martitização, havendo substituição gradativa dos cristais a partir das bordas, das fraturas e dos planos de clivagem. Tal processo é incipiente na base do horizonte, porém torna-se mais intenso em direção ao topo, onde individualizam-se núcleos residuais de magnetita envoltos por hematita de transformação (Fig. 7B).

HORIZONTE SAPROLITICO Neste horizonte foi possível distinguir dois tipos de saprólito. Da mesma forma que nas rochas matrizes, o contato entre os dois tipos é gradativo.

Saprólito ferruginoso / É proveniente da aiteração das formações ferríferas do Tipo I e possui uma espessura de cerca de 12 metros no perfil F/81 (Fig. 5). Apresenta coloração marrom-escura a avermelhada, aspecto terroso e é normalmente friável. Além da matriz fina, ele comporta, eventualmente, fragmentos e blocos reliquiares de formação ferrífera fortemente alterada. A matriz é composta principalmente de goethita e hematita, além de traços de caolinita e de hidrobiotita. Como minerais resistatos ocorrem magnetita (martitizada), fluorita, quartzo e turmalina.

A goethita é em geral mal cristalizada e apresenta uma substituição isomórfiça de $\mathrm{FeOOH}$ por cerca de 10 moles \% de $\mathrm{AlOOH}$. Ao microscópio, nota-se que a goethita, além de ser o constituinte principal da matriz é componente essencial dos produtos ferruginosos que pre- enchem fraturas nos cristais martitizados da magnetita e exibem geralmente texturas coloformes. Análises na microssonda efetuadas em quatro pontos na amostra coletada a 15,5 metros de profundidade do furo $\mathrm{F} / 81$ mostraram que esses produtos goethíticos possuem teores de 0,8 a $1,9 \%$ de $\mathrm{Al}_{2} \mathrm{O}_{3}$ e de 3,4 a $5,9 \%$ de $\mathrm{SiO}_{2}$, bem como traços de cálcio e magnésio.

A hematita é fundamentalmente produto da transformação pseudomórfica da magnetita através da martitização. Ela ocorre nas bordas e nos planos de clivagem e de fraturas da magnetita, invadindo a parte interna dos cristais.

A hidrobiotita ocorre ocasionalmente em cristais reliquiares fortemente degradadados, dispersos na matriz ferruginosa. O grau de cristalinidade deste mineral tende a diminuir ligeiramente da base para o topo do saprólito ferruginoso.

De forma sintética a distribuição dos minerais no saprólito ferruginoso I do perfil F/81é a seguinte (Fig. 5): goethita e hematita são os minerais mais abundantes neste horizonte, enquanto que hidrobiotita, bastante comum na base do saprólito até cerca de 18 metros de profundidade, passa a ocorrer apenas em traços até a profundidade de 13 metros da superfície, onde desaparece, cedendo lugar a uma caolinita mal cristalizada.

Saprólito ferruginoso // Trata-se do produto de alteração das formações ferríferas do Tipo II. Este saprólito está bem representado no perfil F/79 (Fig. 4) e na porção superior do perfil F/81, no qual mostra contato gradativo com o saprólito ferruginoso I sotoposto (Fig. 5). Sua espessura varia de cerca de 7 metros no perfil $\mathrm{F} / 81$ a 17 metros no perfil F/79. Ele exibe uma coloração cinza-esverdeada na base e amarela-avermelhada no topo, bem como uma textura reliquiar ressaltada pela orientação das palhetas de hidrobiotita. Comparativamente, este saprólito contém uma maior quantidade de argilominerais e um menor conteúdo de oxi-hidróxido de ferro que o saprólito ferruginoso I. No perfil $F / 79$, na passagem da rocha semi-alterada para o horizonte saprolítico, ocorre um nível argiloso de coloração esverdeada, de cerca de 4 metros de espessura, composto principalmente por hidrobiotita, goethita, esmectita e granada ferruginizada (Fig. 4). Devido à sua composição mineralógica, este nível foi distinguido no perfil e denominado saprólito argiloso. A sua passagem para o saprólito ferruginoso II no topo do perfil é marcada por um aumento da quantidade de oxihidróxido de ferro e pela conseqüente diminuição do conteúdo de hidrobiotita. Tais variações composicionais refletem as variações nas proporções de silicatos e de magnetita comumente observadas na rocha matriz. De forma geral, nota-se no perfil $\mathrm{F} / 79$, a seguinte distribuição dos minerais de alteração (Fig. 4): da base do saprólito até 20 metros de profundidade os minerais mais abundantes são hidrobiotita, esmectita, goethita e hematita. De 20 metros até o topo do saprólito passam a dominar, caolinita, goethita e hematita, sendo raras a ausentes, hidrobiotita e esmectita. A esmectita de composição nontronítica é normalmente bem cristalizada e acompanha sistematicamente a hidrobiotita no perfil, desaparecendo com o surgimento da caolinita. Esta última mostra um aumento do grau de cristalinidade em direção ao topo do horizonte. A goethita é mal cristalizada e apresenta uma substituição molar de FeOOH por AlOOH de 8 a 10\%. A hematita resulta principalmente da transformação pseudomórfica da magnetita pelo processo de martitização. Nos sistemas fissurais ocorrem sobretudo goethita e oxi-hidróxidos de manganês, bem como esmectita na base do horizonte. Os principais minerais resistatos são turmalina, quartzo e granada ferruginizada.

No perfil F/81 o saprólito ferruginoso II é constituído principal mente por goethita, hematita e caolinita. No entanto, a proporção desta última é menor que no saprólito ferruginoso II do perfil F/79.

PRODUTOS DE ALTERAÇÃo DOS SULFETOS A alteração dos sulfetos primários resultou na individualização de duas zonas de características texturais e mineralógicas distintas, que ocupam no perfil a parte superior da rocha fresca e a porção inferior a média do horizonte de transição. A zona inferior comporta sulfetos secundários e, localmente, projeta-se a profundidade significativa na rocha fresca, enquanto que a zona superior contém minerais oxidados (Figs. 4 e 5). A distribuição e a composição dessas associações minerais neoformadas são semelhantes às descritas em perfís gossânicos (Sato 1960a,b, Blanchard 1968, Nickel et al. 1974,1977, Blain \& Andrew 1977, Anderson 1982, Nickel 1983, Taylor \& Appleyard 1983, Taylor \& Scott 1983, Thornber 1983, Taylor 1984, Nickel \& Daniels 1985). 


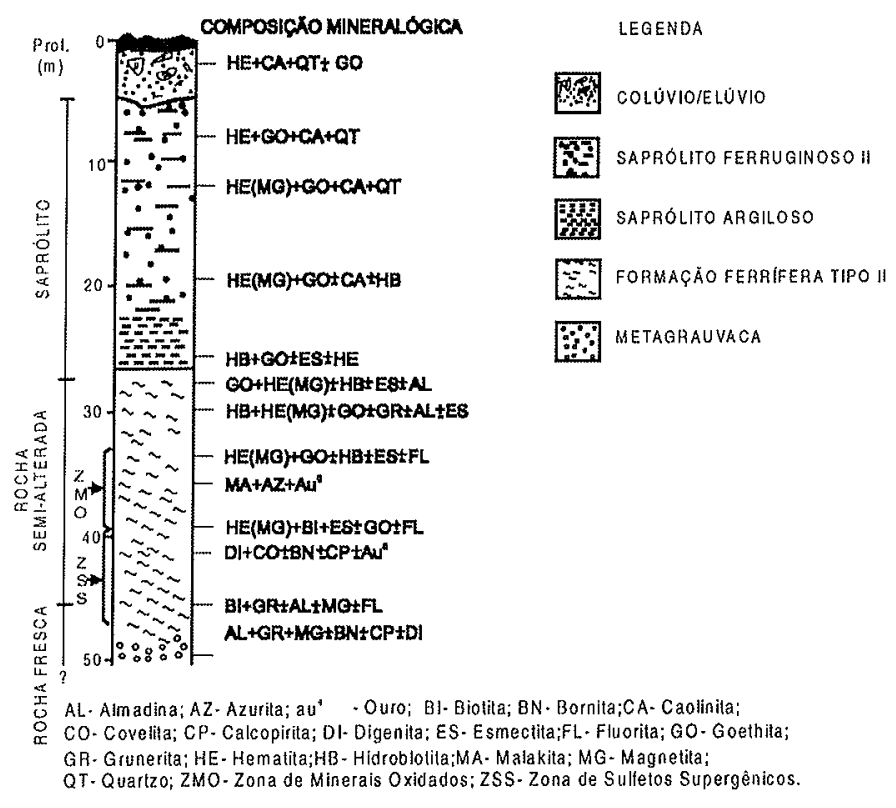

Figura 4 - Perfil de alteração sobre as formações ferrifferas do Salobo (furo de sondagem F/79).

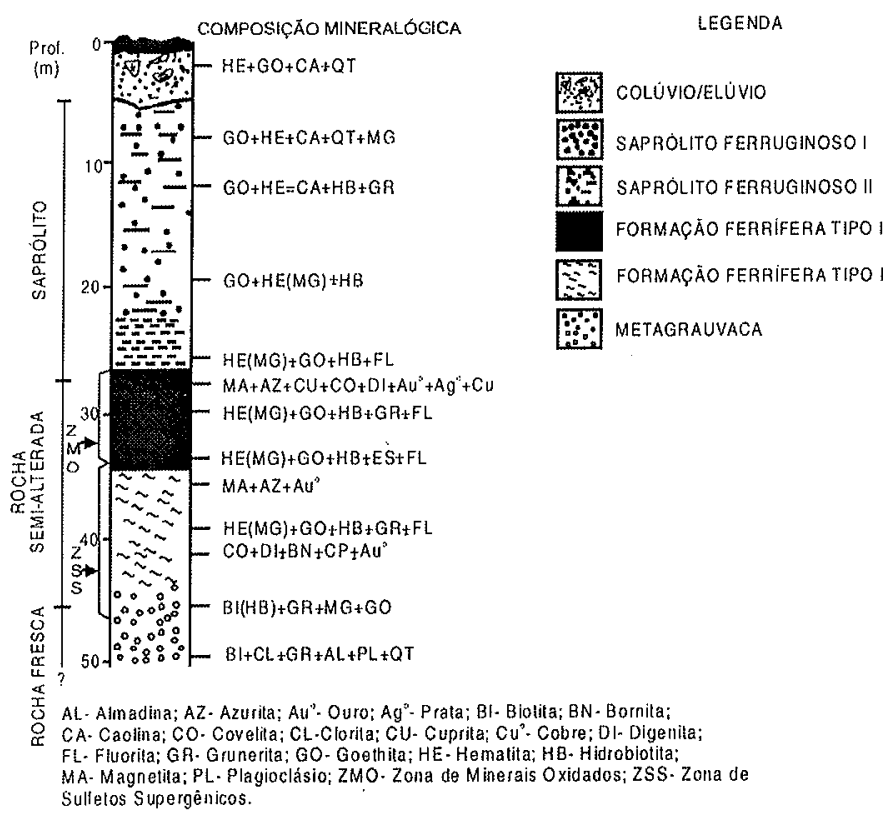

Figura 5 - Perfil de alteração sobre as formaçôs ferríferas do Salobo (furo de sondagem $F / 81$ )

\section{Zona de sulfetos supergênicos}

A zona de sulfetos supergênicos possui uma espessura de 8 a 10 metros nos perfís estudados. Ela é melhor desenvolvida no perfil sobre as formações ferríferas do Tipo I (Fig. 5), enquanto que no perfil sobre as formações ferríferas do Tipo II (Fig. 4) os sulfetos secundários são menos abundantes. De forma geral, esses minerais são mais abundantes entre 40 e 45 metros de profundidade. Localmente, no entanto, podem ser encontrados em fraturas a cerca de 80 metros da superfície, o que mostra que as soluções supergênicas migraram até profundidades consideráveis na propria rocha fresca.

Os minerais mais comuns são digenita e covelita. Eles ocorrem $\mathrm{em}$ cristais anédricos a subédricos de 0,05 a $0,25 \mathrm{~mm}$ de comprimento e preenchem espaços entre os cristais de magnetita e fraturas nestes últimos. Eventualmente, constituem lamelas inseridas nos planos de clivagem da biotita e do anfibólio e nas fraturas da granada. Ao microscópio minerográfico a digenita exibe, sob luz natural, uma colora- ção branca-azulada, que contrasta com a coloração branca-rosada da calcocita. Seu contato com a bornita e a calcocita é irregular. Em estágio menos avançado de alteração da rocha, a digenita ocorre no contato entre a bornita e a calcocita e forma golfos que penetram nos cristais de bornita (Fig. 7C). Essas relações de substituição evoluem em direção ao topo da zona de sulfetos secundários, culminando com a substituição completa da bornita e da calcocita pela digenita. A covelita, por sua vez, exibe coloração azul-escura sob luz natural e mostra o característico efeito de chama quando observada com nicóis cruzados. Seus contatos com a digenita são difusos, destacando-se franjas de covelita que invadem progressivamente da borda para o centro os cristais de digenita. No topo da zona de sulfetos supergênicos, a covelita forma auréolas em torno dos cristais de digenita, sobrando finalmente apenas inclusões reliquiares deste último mineral em cristais de covelita (Figs. 7D e 8A). Localmente, digenita e covelita ocorrem em fraturas nos cristais de magnetita, juntamente com grãos reliquiares de bornita. Não foram observadas relações de substituição direta entre calcopirita e digenita na zona de sulfetos supergênicos. No entanto, podem ser observadas diminutas inclusões reliquiares de calcopirita nos cristais de bornita, sendo esses últimos progressivamente substituídos por digenita e esta por covelita (Figs. 8A e 8B).

Também ocorrem, embora mais raros na zona enfocada, molibdenita, cobaltita e elementos nativos. Os dois primeiros são minerais primários residuais. A molibdenita ocorre em cristais fibrosos de 0,2 a 0,4 mm de comprimento, às vezes recurvados, mostrando contatos retilíneos com a magnetita. A cobaltita aparece em cristais euédricos ( 0,01 a $0,03 \mathrm{~mm}$ de comprimento), contendo eventualmente minúsculas inclusões de calcopirita. Os elementos nativos são cobre, prata e ouro. Eles ocorrem principalmente em fraturas nos cristais de magnetita e, no caso específico do ouro, também na forma de inclusões neste mineral. O cobre nativo apresenta-se em grãos anédricos de tamanho superior a $0,5 \mathrm{~mm}$, localizados em fraturas nos cristais martitizados de magnetita juntamente com oxi-hidróxidos de ferro, na parte superior do horizonte (Fig. 8C). A prata ocorre em diminutas partículas irregulares, as vezes na forma de agregados alojados em fraturas e fissuras nos cristais martitizados de magnetita. Enfim, as partículas de ouro são geralmente placóides e possuem tamanho entre 0,002 e $0,06 \mathrm{~mm}$. As partículas maiores ocorrem geralmente em fraturas e fissuras na magnetita, enquanto que as menores formam agrupamentos de minúsculas inclusões nos cristais de magnetita.

Zona de minerais oxidados A zona de minerais oxidados é constituída principalmente por hematita e goethita e por óxidos e carbonatos de cobre em menores quantidades. Além desses minerais, esta zona contém ainda, na sua base, raros cristais reliquiares de sulfetos. É mais desenvolvida sobre as formações ferríferas do Tipo I, onde pode alcançar 9 metros de espessura (Fig. 5), e é mais irregular no domínio das formações ferríferas do Tipo II. Os principais minerais secundários de cobre são malaquita, azurita e cuprita, que ocorrem geralmente na base do horizonte, seja preenchendo fraturas, seja formando incrustações expressivas na rocha. A malaquita e a azurita apresentamse em cristais fibrosos exibindo normalmente um arranjo radial (sobretudo a malaquita) e preenchem um denso sistema de fraturas, estando localmente associadas à esmectita (Fig. 8D). A cuprita é mais rara e ocorre em fraturas junto com oxi-hidróxidos de ferro.

A oxidação dos sulfetos secundários resulta em formação de inúmeras cavidades - moldes de sulfetos pretéritos - dentro dos cristais de magnetita hospedeiros. Em algumas dessas cavidades ainda estão presentes restos de covelita e de digenita envoltos num plasma de coloração marrom-escura, o que mostra que a alteração desses minerais foi incompleta. Da mesma forma, cristais de covelita e de digenita de até $0,05 \mathrm{~mm}$ de comprimento ocorrem localmente em microfraturas da magnetita "protegidos" da oxidação. Ouro, cobre e prata nativos estão presentes principalmente na base do horizonte, seja na forma de diminutas inclusões na magnetita (ouro e prata), seja preenchendo fraturas neste mineral (ouro, cobre e prata).

ALTERAÇÃO SUPERGÊNICA DOS SULFETOS Os primeiros indícios de intemperismo dos sulfetos primários no depósito do Salobo são observados em fraturas e micro-zonas de cisalhamento na rocha sã, a cerca de 80 metros de profundidade. Nesta zona, os cristais de bornita apresentam nas suas bordas delgadas franjas de digenita $e$ de covelita (mais rara), que tendem a invadir progressivamente suas partes mais internas, o que sugere substituição (Fig. 7C). Como indi- 
cado pela profundidade, essas transformaçōes ocorreram em condições redutoras e envolveram, provavelmente, reações entre o sulfato de cobre - gerado na zona de oxidação - e a bornita primária. Tal mecanismo pode ser descrito pela seguinte reação de troca de cátions (Blanchard 1968):

$$
\begin{aligned}
& \mathrm{Cu}_{5} \mathrm{FeS}_{4} \text { (bornita) }+\mathrm{CuSO}_{4} \Rightarrow \\
& \quad 2 \mathrm{Cu}_{2} \mathrm{~S} \text { (calcocita) }+2 \mathrm{CuS} \text { (covelita) }+\mathrm{FeSO}_{4}
\end{aligned}
$$

A substituição da bornita pela digenita foi mais intensa no topo da zona redutora - entre 35 e 45 metros de profundidade - onde predomina a associação digenita+covelita. A intensificação da substituição nesta zona indica que a ação das soluções contendo sulfato de cobre foi mais eficiente na zona de flutuação do lençol freático do que a maior profundidade. Este fato se deve ao consumo do sulfato de cobre no processo de troca iônica nas zonas mais próximas à superfície - e a sua conseqüente escassez em profundidade - ou à neutralização das soluções supergênicas por reação com minerais da ganga (silicatos e carbonatos).

O mecanismo de transformação supergênica da calcopirita não pôde ser determinado com precisão devido não terem sido observadas as relações texturais entre este mineral e os sulfetos supergênicos. No entanto, a escassez de calcopirita na zona de sulfetos secundários e a presença de grãos reliquiares deste mineral no interior de cristais de bornita - esses últimos exibindo auréolas e franjas de digenita e de covelita (Figs. 8A e 8B) - sugerem que a calcopirita foi provavelmente desestabilizada sob condiçôes oxidantes e, em seguida, substituída parcial a totalmente pela bornita. Posteriormente, esta última foi transformada sob condições algo mais oxidantes, para digenita e covelita (Fig. 7D, 8A e 8B). Deste modo, acredita-se que parte da bornita encontrada na porção superior da zona de sulfetos secundários provém da transformação supergênica da calcopirita.

As relações texturais entre calcocita, digenita e covelita sugerem uma substituição progressiva do primeiro mineral pelo segundo e deste último pelo terceiro (Figs. 7D e 8A). Tais relações podem ser explicadas considerando a estabilidade desses minerais no ambiente supergênico. Segundo trabalhos experimentais desenvolvidos no sistema Cu-S (Roseboom Jr 1966), a digenita $\left(\mathrm{Cu}_{1,8} \mathrm{~S}\right)$ é a fase intermediária entre a covelita $(\mathrm{CuS})$ e a calcocita $\left(\mathrm{Cu}_{2} \mathrm{~S}\right)$, sendo estável a temperaturas de $0^{\circ} \mathrm{C}$ a $76^{\circ} \mathrm{C}$. Por sua vez, a calcocita ortorrômbica é estável a temperaturas de $0^{\circ} \mathrm{C}$ a $103^{\circ} \mathrm{C}$ e a covelita entre $0^{\circ} \mathrm{C}$ e $157^{\circ} \mathrm{C}$. Assim, os três minerais pertencem ao sistema $\mathrm{Cu}-\mathrm{S}$ e podem se formar nas condições supergênicas, dependendo da razão $\mathrm{Cu} / \mathrm{S}$ nas soluções e das condições de Eh e pH no ambiente (Fig. 6). No caso em questão, a quantidade de digenita e de covelita aumenta nos níveis superiores da zona de sulfetos secundários, enquanto que a calcocita torna-se menos abundante, havendo uma diminuição progressiva da razão $\mathrm{Cu} / \mathrm{S}$. Acredita-se que tal quadro resulta da desestabilização da calcocita na parte superior da zona redutora afetada pela flutuação do nível hidrostático e da conseqüente formação de digenita e de covelita em condições algo mais oxidantes (Fig. 6). Este processo é expresso pela seguinte reação:

$$
\begin{aligned}
& \mathrm{Cu}_{2} \mathrm{~S} \text { (calcocita) }+2 \mathrm{O}_{2} \Rightarrow \\
& \quad \mathrm{CuS} \text { (covelita) }+\mathrm{CuSO}_{4} \text { (Sato 1992) }
\end{aligned}
$$

Na zona de oxidação, malaquita e azurita foram geradas por reação do sulfato de cobre com a calcita presente nos veios, em condições de pH neutro a alcalino (Anderson 1982). O cobre nativo deve ter sido precipitado em condições levemente redutoras ou ter-se formado por oxidação direta da bornita e da calcocita, de acordo com as seguintes reações (Blanchard 1968):

$$
\begin{gathered}
4 \mathrm{Cu}_{5} \mathrm{FeS}_{4}(\text { bornita })+6 \mathrm{H}_{2} \mathrm{O}+35 \mathrm{O}_{2} \\
16 \mathrm{CuSO}_{4}+4 \mathrm{Cu}^{\circ}+4 \mathrm{Fe}(\mathrm{OH})_{3}
\end{gathered} \Rightarrow
$$

$\mathrm{Cu}_{2} \mathrm{~S}$ (calcocita) $+2,5 \mathrm{O}_{2}+\mathrm{H}_{2} \mathrm{O} \Rightarrow$

$$
\mathrm{Cu}^{\circ}+\mathrm{CuSO}_{4}+2 \mathrm{OH}^{-}
$$

Um processo semelhante deve ter levado à formação da cuprita, conforme as reações abaixo:

$$
\begin{aligned}
& 4 \mathrm{Cu}_{5} \mathrm{FeS}_{4} \text { (bornita) }+37 \mathrm{O}_{2}+6 \mathrm{H}_{2} \mathrm{O} \Rightarrow \\
& 16 \mathrm{CuSO}_{4}+4 \mathrm{CuO} \text { (cuprita) }+4 \mathrm{Fe}(\mathrm{OH})_{3} \\
& \mathrm{Cu}_{2} \mathrm{~S} \text { (calcocita) }+3 \mathrm{O}_{2}+\mathrm{H}_{2} \mathrm{O} \Rightarrow \\
& \mathrm{CuSO} 4+\mathrm{CuO} \text { (cuprita) }+2 \mathrm{OH}^{-}
\end{aligned}
$$

As reações acima indicam que durante a alteração da bornita e da calcocita, uma parte substancial do cobre é lixiviada - $4 / 5$ do cobre, no caso da bornita - enquanto que outra parte permanece "in situ" na forma de cobre nativo ou de cuprita (CuO), dependendo das condições de Elh do ambiente (Fig. 6).

A dissolução dos sulfetos na parte superior da zona de oxidação deixou inúmeras cavidades nos cristais de magnetita. A ausência de oxi-hidróxidos de ferro nessas cavidades indica que este elemento foi lixiviado nas condições ácidas geradas pela oxidação dos sulfetos (Blanchard 1968). A remobilização do ferro é atestada pelas texturas coloformes dos depósitos goethíticos na zona de oxidação. Por outro lado, a presença de grãos reliquiares de sulfetos em algumas dessas cavidades, sugere que a dissolução completa desses minerais foi impedida pelo efeito protetor da magnetita e/ou pela fraca acidez das soluções supergênicas. No primeiro caso, o caráter refratário à alteração da magnetita e o acesso restrito das soluções nas partes internas dos cristais devem ter inibido a destruição total das inclusões de sulfetos. No segundo caso, a fraca acidez do meio decorre da composição específica da associação de sulfetos do depósito do Salobo - bornita, calcopirita, calcocita, digenita, covelita - a qual comporta quase exclusivamente minerais pobres em ferro ou não contendo este elemento, $e$ apresentando uma razão metal/enxofre $\geq 1$. Tal associação é pouco favorável à geração de ácido livre durante o intemperismo (Blanchard 1968, Nickel \& Daniels 1985, Taylor 1987), o que deve ter limitado ou pelo menos retardado a degradação dos sulfetos. Soma-se a tais fatos a influência dos carbonatos presentes nos veios que provocou a neutralização das soluções ácidas na zona de oxidação e a precipitação de carbonatos hidratados de cobre (malaquita, azurita).

A magnetita, por sua vez, manteve a sua estrutura original até os níveis superiores do perfil de alteração, sofrendo, no entanto, uma substituição gradativa pela hematita.

CONCLUSÕES O perfil de alteração observado na área Salobo é de tipo truncado e composto em sua maior parte pelo saprólito inferior que, embora algo modificado pelo intemperismo mais recente, preserva ainda as características texturais e composicionais das rochas matrizes.

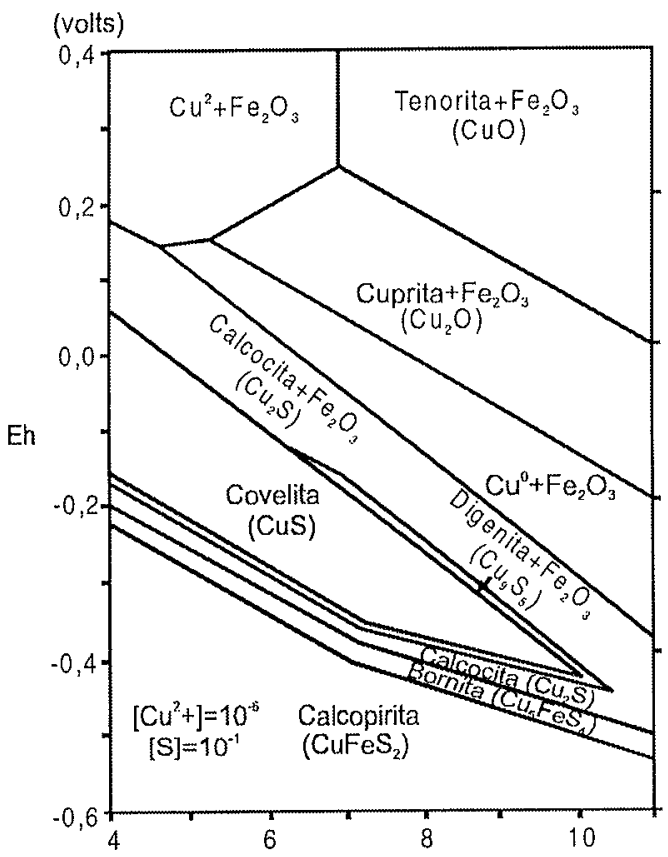

Figura 6 - Diagrama de estabilidade Eh-pH dos sulfetos de cobre no sistema $\mathrm{Cu}-\mathrm{Fe}-\mathrm{S}-\mathrm{O}-\mathrm{H}-\mathrm{a} 25^{\circ} \mathrm{C}$ e l atm. (Modificado de SATO 1992) 

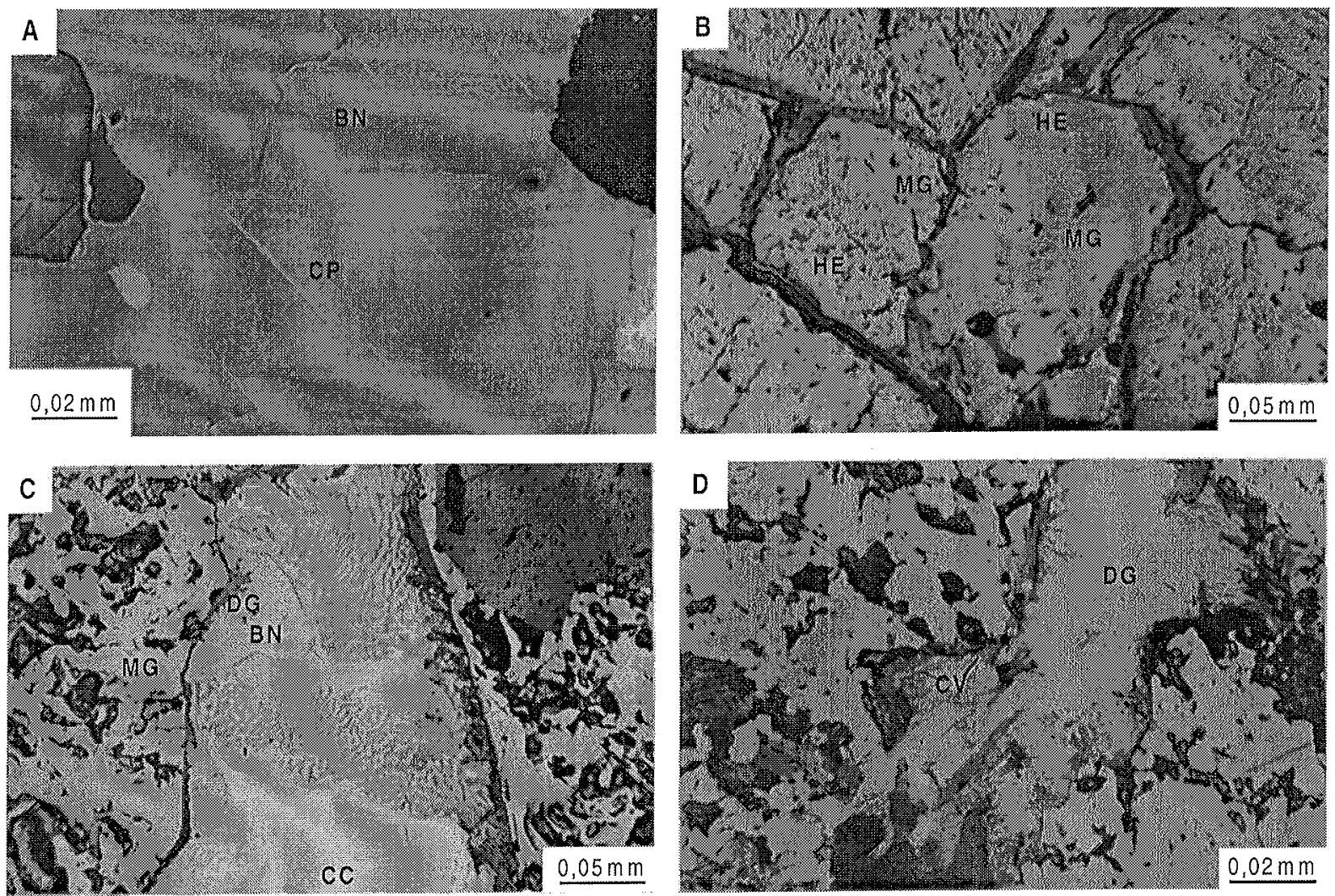

Figura 7- Fotomicrografias das formacões ferriferas do Salobo. (A) Cristais aciculares de calcopirita (CP) orientados nos planos de clivagem da bornita (BN) (amwstra F/39/366m): (B) Substituiçäo da magnetita $(M G)$ por hematita (HE) (martitizaçá) a partir das bordas, fraturas e planos de clivagem do primeiro mineral (amostra F/81/21,5m); (C) Estágio incipiente da substituição da bornita $(B N)$ pela digenita $(D G)$ na zona de sulfetos secundários. Notar a evolução do processo a partir das bordas do cristal de bornita e a textura de intercrescimento mirmequítico desse mineral com a calcocita (CC). Vide ainda contatos vetilíneos da bornita com a magnetita $(M G)$ (amostra $F / 52 / 145,0 m) ;(D)$ Substituição da digenita $(D G)$ pela covelita (CV) na porção superior da zona de sulfetos supergênicos. Observar a evolução do processo ao longo das bordas e dos planos de clivagem da digenita (amostra F/81/42,5m).
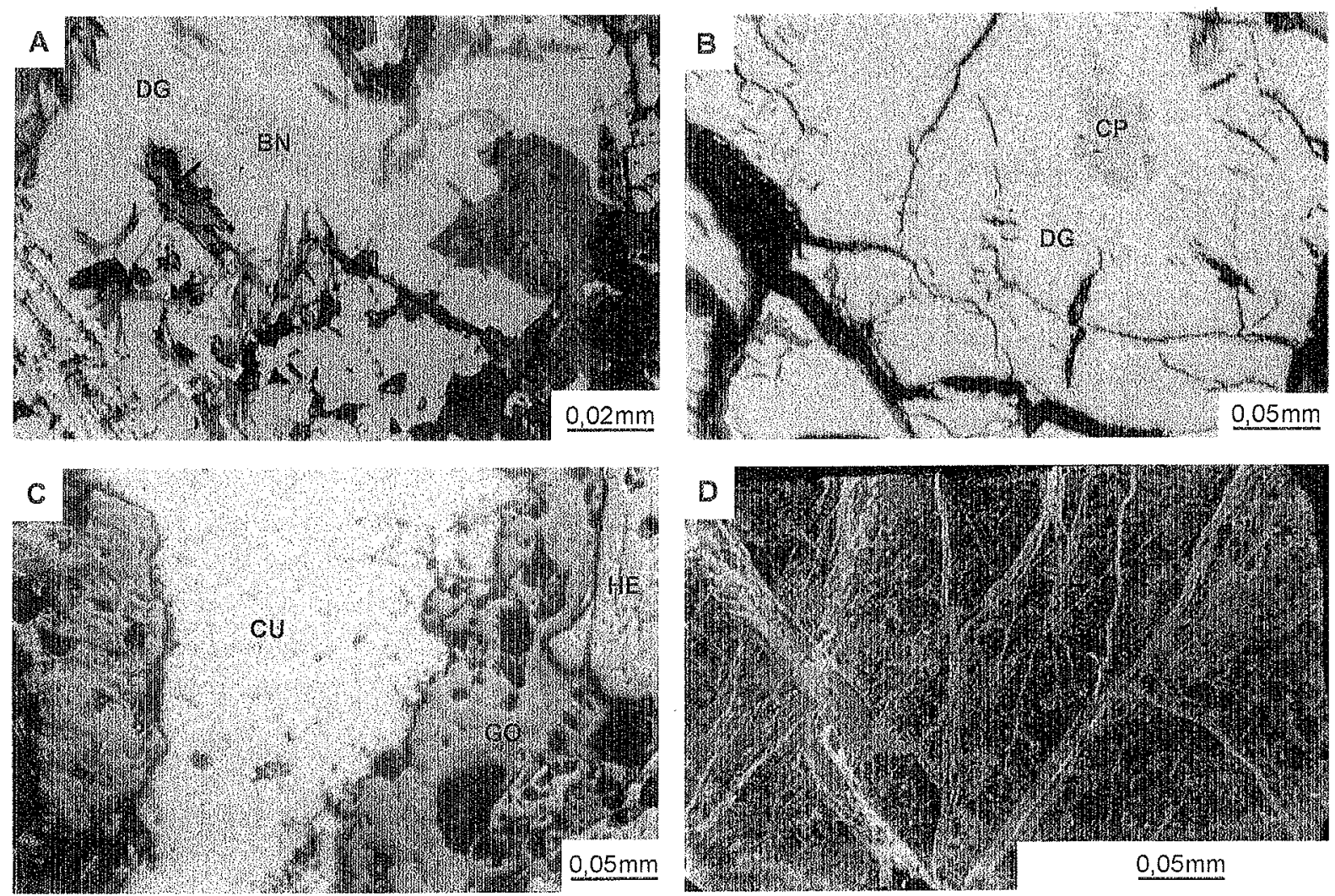

Figura 8-Fotomicrografias das formaçöes ferriferas do Salobo. (A) e (B) Inclusões reliquiares de bornita (BN) e calcopirita (CP) em cristais de digenita neoformados $(D G)$ e substituição destes últimos a partir das bordas e das fraturas por cristais de covelita $(C V)$ (amostra F/81/38, Om); (C) Cobre nativo (CU) e goethita $(G O)$ alojados entre cristais martitizados de magnetita (HE) na parte superior da zona de sulfetos supergênicos (amostra F/81/38,Om); (D) Malatuita (cinza claro) e smectita (cinza escuro) preenchendo fraturas e fissuras nas formaçóes ferriferas do Tipo I. 
O intemperismo gerou uma cobertura de alteração exibindo variações laterais, texturais e mineralógicas, que refletem a composição heterogênea do substrato e a disposição subvertical das camadas que 0 constituem. Com efeito, a degradação das metagrauvacas estéreis deu orígem a um saprólito rico em argilominerais - hidrobiotita, esmectita e caolinita - derivados principalmente da alteração da biotita. Por outro lado, a alteração das formações ferriferas hospedeiras dos sulfetos primários de cobre (bornita, calcocita, calcopirita) originou um perfil tipicamente gossânico, o qual é composto, da base para o topo, por uma zona de sulfetos supergênicos (covelita, digenita, bornita ?), uma zona de minerais oxidados (malaquita, azurita, cuprita, $\mathrm{Cu}^{\circ}$ ) e por um saprólito ferruginoso. As duas primeiras zonas ocupam no perfil a parte superior da rocha fresca $\mathrm{e}$ a porção inferior a média do horizonte de transição. A extensão lateral dessas zonas normalmente não ultrapassa o domínio das lentes de formação ferrífera.

A formação da assembléia de sulfetos e óxidos supergênicos envolveu, inicialmente, a dissolução dos sulfetos primários na zona de oxidação e a mobilização do Cu e do Fe sob a forma de sulfatos. A migração das soluções em direção ao lençol freático permitiu a transferência de Cu para níveis mais profundos e resultou em formação de uma nova associação mineral de acordo com a razão $\mathrm{Cu} / \mathrm{S}$ nas soluções e as condições de Eh e pH do meio (Fig. 6). Na zona redutora - abaixo do nível hidrostático - as reações de troca iônica entre o sulfato de cobre e os sulfetos primários resultaram em geração de digenita e covelita, enquanto que na zona de flutuação do lençol freático e logo acima, em condições levemente mais oxidantes, o cobre precipitou na forma de cuprita e de cobre nativo. Por outro lado, a reação do sulfato com a calcita dos veios que cortam as formações ferríferas criou condições de $\mathrm{pH}$ neutro a alcalino que permitiram a precipitação de malaquita e azurita.

O lento soerguimento tectônico da região de Carajás, ocorrido no Terciário Superior e no Quaternário (Kotschoubey et al. 1989, Souza \& Kotschoubey 1991, Maurity \& Kotschoubey 1995), ocasionou o rebaixamento do nível hidrostático e o aprofundamento da cobertura de alteração formada no Terciário Inferior. Na área do Salobo, este processo resultou em dissecação do manto laterítico pretérito e em remoção da couraça e da porção superior do saprólito. Concomitantemente, em cada fase de rebaixamento do nível hidrostático e conseqüente aprofundamento do perfil, ocorreu desestabilização dos óxidos e sulfetos previamente gerados, sendo parte do cobre lixiviada per descensum e reprecipitada nas zonas de cimentação e oxidação reconstituídas a maior profundidade e outra parte fixada in situ por goethita e argilominerais neoformados.

Agradecimentos Ao CNPq e a FINEP pelo apoio financeiro; ao Curso de Pós-Graduação em Geologia e Geoquímica do Centro de Geociências da UFPa por proporcionar a realização do doutorado do primeiro autor; a CVRD pelo apoio nos trabalhos de campo e pela liberação dos furos de sondagem para estudo; ao Prof. Dr. Bernard Hieronymus da Universidade de Paris VI pela realização de algumas análises na microssonda eletrônica e a dois revisores anônimos da RBG pela análise crítica do manuscrito.

\section{Referências}

Anderson A.J. 1982. Characteristics of leached capping and techniques of appraisal. In Titley SR (ed.) Advances in geology of the porfhyry copper deposits, Southvestern North America. Tucson, Univ. Arizona, 275-295.

Blain C.E \& Andrew R.L. 1977. Sulfide weathering and the evaluation of gossans in minera exploration. Minerals Sciences and Engineering, 9:119-150.

Blanchard R. 1968. Interpretation of leached outcrops. Nevada Bureau of Mines Bulletin. 66:1-196.

Brindley G.W., Zalba P.E., Bethke C.M. 1983. Hydrobiotite, a regular 1:1 interstratification .

Carrol D. 1974. Clay minerals: a guide to their $x$-ray identification. California, Geological Society of America, $80 \mathrm{p}$.

Craig J.R. \& Vaughan D.J. 1981. Ore microscopy' and ore petrography. New York, John Wiley \& Sons, $406 \mathrm{p}$

Figueiredo B.R., Réquia K.C.M., Xavier R.P. 1993. The Salobo ore deposit, district of Carajăs, northern Brazil: a mineralogical and geochemical study. In: SBGq, Congresso Brasileiro Geoquímica, 4., Brasília, Resimos Expandidos, 177-180.

Flores S.M.P. 1989. Mineralogia e geoquímica da coberfura de alferacão do depósito de Salobo, Serra dos Carajás. Centro de Geociências, Universidade Federal do Pará, Belém, Tese de Mestrado, 116p.

Ildefonse Ph, Manceau A., Prost D. Toledo-Groke M.C. 1986. Hidroxy-Cu-vermiculite formed by the weathering of Fe-biotites at Salobo, Carajás, Brazil. Clays \& Clays Minerals, 34:338-345.

Kotschoubey B., Truckenbrodt W., Hieronymus B., Alves C.A. 1989. Preliminary study of alu aluminous laterites and bauxites from Serra Notte (Carajas

Lindenmayer Z.G. 1990. Salobo Sequence, Carajás, Brazil: geology, geochemistry and metamorfism. University of Western Ontario, Canadá, Tese de Doutoramento, 405p.

Maurity C.W. \& Kotschoubey B. 1995. Evolução recente da cobertura de alteração no platô $\mathrm{N} 1$ - Serra dos Carajás-Pa. Degradação, pseudocarstificação, espeleotemas. Boletim do Museu Paraense Enilio Goeldi, 7:331-362.

Nickel $E$. R.E. Smith (ed.) Geochemical exploration in deeply weathered terrain. Western Australia, CSIRO, 73-86.

Nickel E H \& Daniels J.L. 1985. Gossans. In: K.H. Wolf (ed.) Handbork of Strata-Bound and Stratiform ore deposits. Amsterdan, Elsevier: 261-390.

Nickel E.H., Allchurea P.D. Mason M.G., Wilmshurst J.R. 1977. Supergene alteration at the Perseverance nickel deposit, Agnew Western Australia Econ Geol. 72:184-203.

Nickel E. H. Ross J.R. Thornber M.R. 1974. The supergene alteration of pyrrotite pentlandite ore at Kambalda, Western Australia. Econtomic Geology, 69:93-107.

Pinto da Silva E.R. 1996. Geologia e Geoquimica das Mineralizaç̃es Supergênicas de Ouro das Areas Salobo e Pojuca-Leste, Serra dos Carajás. Centro de Geociências, Universidade Federal do Pará, Belém, Tese de Doutoramento, 206p.

Pinto da Silva E.R., Kotschoubey B., Hieronymus B. 1991. Perfil de Intemperismo do Salobo, Serra dos Carajás-PA e o comportamento geoquímico do ouro. In: SBG Núcleo Norte, Simp. Geol. Amaz., 3, Belém, Anais, 1:555-568.

Réquia K.C.M. 1995. O papel do metamortismo e fases fluidas na gênese da mineralizaça de cobre de Salobo. Provincia Mineral de Carajás. Instituto de Geociências, Universidade Estadual de Campinas, Campinas, Tese de Mestrado, 103p.

Réquia K.C.M., Xavier R.P., Figueiredo B. 1994. Evolução paragenética, textural e das fase fluidas no depósito polimetálico do Salobo, Província Mineral dos Carajás-Pa. In: fluidas no depósito polimetálico do Salobo, Província Mineral dos Carajas-Pa. In

Roseboom Jr E.H. 1966. An investigation of the system Cu-S and some natural copper sulfides between $25^{\circ}$ and $700^{\circ}$. Economic Geology; 61:641-672
Santos A.B. 1989. A espectroscopia de absorção no infravermelho no estudo de alterafoñes geoquimicas de minerais de cobre e silicatos associados (Regiāo da Serra dos Carajás-Pa). Centro de Geociências, Universidade Federal do Pará, Belém, Tese de Mestrado, 98p.

Sato M. 1960a. Oxidation of sulfide ore bodies I. Geochemical environments in terms of El and pH. Econ. Geol., 55:928-961.

Sato M. 1960 b Oxidation of sulfide ore bodies II. Oxidation mechanisms of sulfide minerals at $25^{\circ} \mathrm{C}$. Econ. Geol., 55:1202-1231.

Sato M. 1992. Persistency-field Eh-pH diagrams for sulfides and their aplication to supergene oxidati

Souza C.I.J. \& Kotschoubey B. 1991. Alguns aspectos micromorfológicos e gênese da cobertura residual sobre as rochas sedimentares da aba notte da Serra dos Carajás-Pará bertura residual sobre as rochas sedimentares da aba norte da Serra dos Car.

Solymar K. 1969. Alumogoethit in den ungarishen bauxiten. Ann. Inst. Geol. Publ. Hung. Budapest, 54:359-373.

Taylor G.F. 1984. Gossan profiles developed above stratabound sulphide mineralization Jou: Geochenical Exploration, 22:351-352

Taylor G.F. 1987. Gossan and ironstone evaluation in mineral exploration. In: SBGq Course Notes, Rio de janeiro, $78 \mathrm{p}$

Taylor G.F. \& Appleyard E.C. 1983. Weathering of $\mathrm{Zn}-\mathrm{Pb}$ lode, Dugald River, Northwest Queenslan 1: The gossan profile. Jotr: Geochemical Exploration, 18:87-110.

Taylor G.F. \& Scott K.M. 1983. Weathering of $\mathrm{Zn}-\mathrm{Pb}$ lode, Dugald River, Northwes Queensiand II: Surface mineralogy and geochemistry. Jour: Geochemical Exploration, 18:111-130.

Thornber M.R. 1983. The chemical processes of gossan formation. In: R. E. Smith (ed.) Geochenical exploration in deeply weathered terrain. Western Australia, CSIRO. $67-76$

Toledo-Groke MC 1986 .ntemperismo dos rochas mineralizadas en cobre do Salobo $3 \mathrm{~A}$ Serra dos Carajás, $P A$ - Mecanismos de alteração dos minerais primários e localizacão do cobre nos produtos secundários. Instituto de Geociências, Universidade de São Paulo, São Paulo, Tese de Doutoramento, 173p.

Toledo-Groke M.C., Melfi A.J., Parisot J.C. 1987. Comportamento do cobre durante intemperismo das rochas xistosas cupriferas de Salobo $3 \mathrm{~A}$, Serra dos Carajás/Pa. Geochimica Brasiliensis, 1:187-207.

Toledo-Groke M.C., Prost D., Ildefonse P., Melfi A.J., Deivigne J., Parisot J.C. 1985. Alteração dos minerais na zona supergênica da formação cuprífera do Salobo $3 \mathrm{~A}$ (Serra dos Carajás, PA) - Localização do cobre nos produtos secundários. Revisła Brasileira de Geociências, 15: 293-299.

Van Olphen H. \& Fripiart J.J. 1979. Data handbook for clay materials and other non metallic minerals: Oxford, Pergamon Press, 346p.

Veiga MM 1983. Propriedades geoquímicas da ligacão cobre-óxidos hidratados de ferm: un estudo do minério alterado do Salobo $3 A-$ Serra dos Carajás-Pa. Universidade Federal Fluminense, Rio de Janeiro, Tese de Mestrado, $182 \mathrm{p}$.

Vieira E.A.P. Saueressig R., Siqueira J.B., Silva E.R.P., Rêgo J.L. Castro F.D.C. 1988 Caracterização geológica da jazida polimetálica do Salobo $3 A$ - Reavaliação. In SBG, Congresso Brasileiro Geologia, 35, Belém, Anexo aos Anais, 97-111.

Wilson M.J. 1970. A study of weathering in soil derived from a biotite-hornblend rock 1 Weathering of biotite. Clays and Clay Minerals, 8:291-303

Manuscrito A-1100

Recebido em 24 de junho de 1999

Revisão dos autores em 25 de janeiro de 2000 Revisão aceita em 31 de janeiro de 2000 